Hum. Hered. 1980;30:I-VI

\title{
Contents, Vol. 30, 1980
}

Founded 1950 as ‘Acta Genetica et Statistica Medica’ by Gunnar Dahlberg

Editors:

M. Hauge, Odense L. Beckman, Umeå

Editorial Board:

L. Gedda, Rome

R. Grubb, Lund

K. Henningsen, København

D. Klein, Geneve

T. Larsson, Stockholm

H. Lehmann, Cambridge

Margareta Mikkelsen, København

J. Mohr, København

A. E. Mourant, London

H. Nachtsheim, Berlin

J. V. Neel, Ann Arbor, Mich.

P. O. Pedersen, København

Marianne Rasmuson, Umeå S. Refsum, Oslo L. D. Sanghvi, Bombay M. Siniscalco, Napoli T.

Sjörgen, Göteborg E. T. O. Slater, London A. C. Stevenson, Oxford

E. Strömgren, Risskov

R. Turpin, Paris

F. Vogel, Heidelberg

M.Whittacker, Exeter

A. C. Allison, Harrow

A. G. Beam, New York, N.Y

K. Berg, Oslo

J. A. Book, Uppsala

L. L. Cavalli-Sforza,

Stanford, Calif. T. J. David, Manchester

E. Essen-Möller, Lysekil

F. C. Fraser, Montreal

J. A. Fraser Roberts, London

N. Freire-Maia, Curitiba

J. Frézal, Paris

$\mathrm{S} \cdot$ Karger $\cdot$ Basel $\cdot$ München $\cdot$ Paris $\bullet$ London $\cdot$ New York $\cdot$ Sydney 
Drug Dosage.

The author and publisher have exerted every effort to ensure that drug selection and dosage set forth in this text are in accord with current recommendations and practice at the time of publication. However, in view of ongoing research, changes in government regulations, and the constant flow of information relating to drug therapy and drug reactions, the reader is urged to check the package insert for each drug for any change in indications and dosage and for added warnings and precautions. This is particularly important when the recommended agent is a new and/or infrequently employed drug.

All rights reserved.

No part of this publication may be translated into other languages, reproduced or utilized in any form or by any means, electronic or mechanical, including photocopying, recording,

microcopying, or by any information storage and retrieval system, without permission in writing from the publisher.

S.KargerAG, P.O.Box,4009 Basel (Switzerland)

Printed in Switzerland by Buchdruckerei National-Zeitung + Basler Nachrichten AG, Basel

Contents Vol. 30,1980

No. 1

Original Paper

Alpha-1-Antitrypsin Phenotypes in French Canadian Newborns

Joly, J.; Richer, G.; Boisvert, F., and Laverdière, M 1

Survey on Haemoglobin Variants, ß-Thalassaemia, Glucose-6-Phosphate Dehydrogenase

Deficiency and Haptoglobin Types in Turkish People Living in Manavgat, Serik and Boztepe

(Antalya)

Aksoy, M.; Dinçol, G., and Erdem, S 3

Interaction of Sickle Cell Trait and Glucose-6-Phosphate Dehydrogenase Deviciency in

Cameroon

Bernstein, S.C.; Bowman, J.E., and Kaptue Noche, L

Transferrin, Haptoglobin and Group-Specific Component Types in Tribal Populations of Andhra Pradesh

Goud, J. D. and Rao, P.R 12

The' 18' Variant of Human Placental Alkaline Phosphatase is Identical to the 'D-Variant'

Doellgast, G.J.; Kennedy, M., and Donald, L.J 18

Sjögren-Larsson Syndrome in Dizygous Twin Sisters

David, TJ 21

Human Red Cell Galactose-1 -Phosphate Uridylyltransferase (EC 2.7.7.12). Electrophoretically

Determined Polymorphism in Denmark and Its Use in Paternity Cases

Eriksen, B. and Dissing, J 27

Genetic Studies of Red Cell Glutamic-Pyruvic Transaminase in Some Japanese Populations

Nishigaki, I.; Itoh, T.; Suzuki, H., and Fujiki, N 33

Properdin Factor B Polymorphism in Afghanistan

Benkmann, H.G.;Goedde, H.W.;Agarwal, D.P.;Flatz, G.;Rahimi, A.;Kaifie, S., andDelbrück, H.... 39 Haptoglobin Types in Breast Carcinoma

Tsamantanis, C; Delinassions, J.G.; Kottaridis, S., and Christodoulou, C 44

C3 Polymorphism in Patients with Chronic Uremia

Stoffersen, E. and Jørgensen, K.A 46

Hemoglobin New York Associated with Alpha-Thalassemia 
Kendalí, A. and Pang, W 50

GPT Polymorphism in the Population of Bologna and Linkage Analysis with Beta-Thalassaemia Facchini, F.; Gruppioni, G.; Veronesi-Martuzzi, F., and Zannotti, M 54

A Further Report on a Kindred with Cases of $4 p$ Trisomy and Monosomy

Mortimer, J.G.; Chewings, W.E., and Gardner, RJ.M 58

Association of Glyoxalase I Allotypes with Graves' Disease and Diabetes mellitus

Moens, H.; Payne, R.; Carter, N.D., and Farid, N.R 62

No. 2

Original Paper

Twin Studies and Substrate Differences in Platelet Monoamine Oxidase Activity

Hussein, L.; Sindarto, E., and Goedde, H.W 65

Use of Multiple Logistic Analysis in Twin Zygosity Diagnosis

Sarna, S. and Kaprio, J 71

Serum Levels of Alpha-1-Antitrypsin in Individuals with Different Pi M Subtypes

Beckman, G. and Beckman, L 81

IV

Contents

Duplication of Region $2 q 31 \rightarrow 2 q$ ter in a Family with 2/9 Translocation

Howard-Peebles, P.N. and Goldsmith, J.P 84

Determination of Parental Heterozygosity in Dermatoglyphic Characters

Bener, A 89

A Population Genetic Study on the Ag Polymorphism in South African Indians and Negroids

Hitzeroth, H. W.; Butler, R., and Bütler-Brunner, E 94

A Note on Gene Frequency Estimation with Misclassification Present

Selvin, S '. 104

Pi Phenotypes in North American Workers: Racial Differences and Comparisons with Reported

Frequencies

Ashley, M.J.; Chan-Yeung, M, and Corey, P.N 107

Heritability Estimates of Somatotype Components Based upon Familial Data

Bouchard, C; Demirjian, A., and Malina, R.M 112

Frequency of Gc Alleles and a Variant Gc Allele in Iceland

Karlsson, S.; Arnason, A.; Thordarson, G., and Olaisen, B 119

Different Expressions of One Gene for Congenital Achromatopsia with Amblyopia in Northern

Sweden

Nordstrom, S. and Polland, W 122

No. 3

Original Paper

AlphapAntitrypsin Phenotypes in Northern Sweden

Beckman, G.; Beckman, L., and Nordenson, $1 \quad 129$

Red Cell Glutathione Peroxidase in Various Jewish Ethnic Groups in Israel

Golan, R.; Ben Ezzer, J., and Szeinberg, A 136

Comparative Study of Red Cell Enzymes in Mirpur (a Portuguese-Descendant Community) and

a Neighbouring Hindu Population of Gopalchak

Bharati, P.; Ghosh, A.K.; Dey, B.; Das, S.K.; Roy, M.; Banerjee, S., and Gupta, R 142

Maternal Age and Dermatoglyphic Asymmetry in Man: Another Look

Young, R.S. and Reed, T 145 
Partial Lipodystrophy and Familial C3 Deficiency

McLean, R.H. and Hoefnagel, D 149

Serum IgE Levels in Twins

Sistonen, P.; Johnsson, V.; Koskenvuo, M., and Aho, K 155

Mitochondrial Malic Enzyme Polymorphism in an Indian Population

Ghosh, U.; Banerjee, P.K., and Saha, N 159

Genetic Characteristics of Hemophilia A in Chile

Cruz-Cokem, R. and Rivera, L 161

Study of Red Blood Cell and Serum Enzymes in Five Pyrenean Communities and in a Basque

Population Sample

Vergnes, H.|Constans, J.iQuilici, J.C.; Levèvre-Witier, P.; Sevin, J., and Stevens, M

Protein and Enzyme Polymorphisms in Affective Disorders in Northern Greece

Parisi, H.A.; Lanara, E.C.; Triantaphyllidis, CD 181

Effects of Parental Consanguinity on Mortality and Reproductive Function

Lindelius, R. 185

Comparing the 'Family Set' Approach to Estimate Heritability with Other Conventional

Estimators: a Monte Carlo Simulation

Rodriguez, A.; Chakraborty, R., and Schull, W.J

Contents

$\mathrm{V}$

No. 4

Original Paper

Is the HpO Phenomenon in Tropical Populations Really Genetic?

Rougemont, A.; Quilici, M; Delmont, J., and Ardissone, J.P 201

Some Biochemical Polymorphisms in Members of the Gaddi Tribe of Himachal Pradesh

Kaur, H.; Sehajpal, P.K.; Khanna, A.K., and Shrivastava, P.K 204

Isoenzymes of Red Cell Glyoxalase I (EC 4.4.1.5) in a Finnish Population

Uotila, L. and Koivusalo, M 207

Polymorphism of the Sixth Component of Complement (C6) in Norwegian Lapps

Olving, J.H.; Teisberg, P., and Olaisen, B 211

Search for Linkage between Dermatoglyphic Sole Characters and Blood Groups

Bener, A 215

Plasma Protein and Enzyme Polymorphisms in Belgium

Brocteur, J.; Hoste, B., and Andre, A 221

Mohr-Wriedt (A2) Brachydactyly. Analysis of a Large Brazilian Kindred

Freire-Maia, N.; Maia, N.A., and Pacheco, C.N.A 225

Erythrocyte Glyoxalase I and Esterase D Polymorphisms in Four French Populations

Vergnes, H.; Meyer, S.; Weil, D.; Goudemand, J.; Brevière, D.; Sevin, J., and Constans, J 232

Frequencies of Gm and Km Allotypes in the Population of Singapore, Sri Lanka and Punjabis in

North India

Daveau, M.; Rivat, L.; Lalouel, J.M.; Langaney, A.; Roberts, D.F., and Simons, M.J

Polymorphism of the Second Component of Complement (C2) in Graves' Disease

Noel, E.P.; Sampson, L.; Pepper, B.M., and Farid, N.R 245

Electrophoretic Investigation of $\gamma$-Glutamyl-Cyclotransferase from Human Erythrocytes

Board, P.G 248 
Population Studies in Cameroon. Hemoglobin S, Glucose-6-Phosphate Dehydrogenase Deficiency and Falciparum Malaria

Bernstein, S.C.; Bowman, J.E., and Kaptue Noche, L

Short Communications

Glyoxalase I (GLO; EC 4.4.1.5.). Gene Frequency Variation in Iraq

Al-Agidi, S.K.; Papiha, S.S., and Shukri, S.M 259

High Frequency of Ina Antigen Among Iranians and Arabs

Badakere, S.S.; Vasantha, K.; Bhatia, H.M.; Ala, F.; Clarke, V.A.; Moesri, R.; Sommai, S., and

Amin, A.B 262

Book Review 264

No. 5

Original Paper

Dermatoglyphic Traits in an Amish-Mennonite Population in Ontario

Tutton, D.A. and Zachariah, K 265

Glucose-6-Phosphate Dehydrogenase in an Afro-American Population

Calvert, A.F. and Trimble, G.E 271

A Note on the Frequency of Consanguineous Marriages in Reading, England in 1972/1973

Coleman, D.A 278

Properdin Factor B (Bf) as an Exclusion Determinate in Parentage Testing

Dykes, D. and Polesky, $\mathrm{H} \quad 286$

VI Contents

Genetic Studies on the Chenchu Tribe of Andhra Pradesh, India

Ramesh, A.; Blake, N.M.; Vijayakumar, M., and Murty, J.S 291

Alpha-1 -Antitrypsin Types and Chronic Obstructive Lung Disease in an Industrial Community in Northern Sweden

Beckman, G.; Beckman, L.; Mikaelsson, B.; Rudolphi, O.; Stjernberg, N., and Wiman, L.-G 299

Variations on Dermal Ridges in Nine Population Groups of Maharashtra, India. I. Intra- and Interpopulation Diversity

Malhotra, K.C.; Chakraborty, R.; Bhanu, B.V., and Fulmali, P.M 307

Transferrin C Subtypes and Spontaneous Abortion

Beckman, G.; Beckman, L., and Sikström, C 316

Probability Calculations in Pedigrees under Complex Modes of Inheritance

Lalouel, J.M 320

B + -Thalassemia Intermedia. Genetic and Biochemical Study of a Family Including 3 Cases

Philip, T.; Souillet, G.; Philippe, N.; Freycon, F.; Bektas, S.; Morlé, L.; Trabuchet, G., and

Godet, J. 324

Short Communication

Distribution of ABO and Rh (D) Blood Groups among Four Endogamous Groups of Andhra Pradesh

Reddi, A.P.; Mukherjee, B.N., and Ramachandraiah, T 331

No. 6

Original Paper

A New Unstable PI M Variant of dp Antitrypsin in a Finnish Isolate

Frants, R.R. and Eriksson, A.W 333 
Studies on the Immunoglobulin Allotypes of Asiatic Populations. VIII. Immunoglobulin Allotypes among the Tuvinians of the USSR

Schanfield, M.S.; Alexeyeva, T.E., and Crawford, M.H 343

Segregation Analysis of Schizophrenia under a Mixed Genetic Model

Carter, C.L. and Chung, C.S 350

Slow-Moving Serum Albumin Variant in a South Indian Tribal Population

Walter, H.; Veerraju, P., and Hilling, M 357

Glucose-6-Phosphate Dehydrogenase Deficiency in South Vietnamese

Panich, V.; Bumrungtrakul, P.; Jitjai, C; Kamolmatayakul, S.; Khoprasert, B.; Klaisuvan, C;

Kongmuang, U.; Maneechai, P.; Pornpatkul, M.; Ruengrairatanaroje, P.; Surapruk, P.; and

Viriyayudhakorn, S 361

Dermatoglyphic Peculiarities in Hypospadias

Micle, S. and Fried, K 365

Absent dTriradius and Dotting of the Ridges in Siblings

Wertelecki, W.; Plato, C, and Plato, C.C 368

Heritable Salivary Proteins and Dental Disease

Friedman, R.D.; Azen, E.A.; Yu, P.L.; Green, P.A.; Karn, R.C., and Merritt, A.D 372

Transferrin C Subtypes in US Blacks and Whites

Kueppers, F. and Harpel, B.M 376

Short Communication

GLO Polymorphism in Iceland

Karlsson, S.; Arnason, A., and Jensson, Ó 383

Announcements $\quad 386$

Author Index 387

Subject Index 389 